\title{
Weather Conditions and Rumen Temperature and pH in Lidia Cattle
}

García JJ1* ${ }^{1 *}$ Bartolomé DJ ${ }^{1}$, Posado $\mathbf{R}^{1}$, Zúñiga $\mathrm{JA}^{2}$, Montañés $\mathbf{M}^{1}$ and Bodas $\mathbf{R}^{1}$

${ }^{1}$ Sub-Directorate for Research and Technology, Agricultural Technology Institute of Castile and León, Ministry of Agriculture and Livestock, Castilla and Leon Meeting, avd. Filiberto Villalobos, 537770 Guijuelo, Salamanca, Spain

${ }^{2}$ Garcisan Distributions, SL Bernardo Dorado, CP 37008, Salamanca, Spain

\begin{abstract}
The aim of this work was to study the relationship between meteorological parameters (relative humidity, rainfall, temperature and wind speed) and rumen environment ( $\mathrm{pH}$ and temperature) in extensively reared Lidia cattle. Five four year old Lidia breed bulls have been used. All the animals received $10 \mathrm{~kg}$ of a TMR (total mixed rations, ratio forage:concentrate 33:67) per animal and day, supplied by means of unifeed wagon once a day. The bulls had free access to a pasture (dehesa) area of 17 hectares. Rumen $\mathrm{pH}$ and temperature ruminal were continuously measured using a wireless internal $\mathrm{pH}$ and temperature probe. Meteorological parameters (temperature, humidity, rainfall and wind speed) were registered and provided by the AEMET (State Agency of Meteorology). The correlations were performed using the software SPSS 16.0 for Windows. It has been observed that rainfall, relative humidity and temperature have a relationship with rumen environment. Conversely, wind speed does not seem to influence the rumen conditions ( $\mathrm{pH}$ and temperature).
\end{abstract}

Keywords: Bovine; Lidia cattle breed; Meteorology; pH; Temperature

\section{Introduction}

The Lidia is a Spanish native breed that is characterized by its rusticity, demanding a breeding in semi-captivity conditions, in the wildness and in a regime of herds in which hierarchies and territoriality are established [1]. Therefore, this breed is reared in an extensive systems in permanent contact with nature and its bioclimatic environment [1] Throughout its life, Lidia cattle, the greatest exponent of the extensively reared bovine systems, remains in freedom in the dehesa (extensive land generally bounded and dedicated to grazing livestock), without protection or stables, thereby being subjected to an effort of adaptation to the recurring inclement weather, which places animals in a natural state of interaction between the complexity of the biochemical processes of their own organism and the environment that surrounds them $[2,3]$.

Despite being reared extensively, Lidia bulls receive a supplementary ration, whose objective is, on the one hand, provide a sufficient amount of protein and energy (particularly during the last phase of preparation for the bullfight $[4,5]$. On the other hand, the purpose is to prepare a physiological machine capable of performing a supreme muscular effort during the approximately twenty minutes that will remain in the bullring [6].

Although most breeders appreciate the advantages of supplementing with TMR, especially weight gain, there are certain disadvantages associated to this feeding regime, mainly related to the appearance of ruminal acidosis. Thus, Bartolomé showed the presence of this pathology in fighting cattle with a variable incidence depending on the type of injury observed [7]. Thus, they found that $58.5 \%$ of the fought bulls presented ruminal $\mathrm{pH}$ values compatible with the suffering of some type of acidosis, most of them chronic; in addition, $27 \%$ of these bulls had some liver disease and $71 \%$ showed rumen paraqueratosis.

In light of this evidence, farmers try to improve feeding by adjusting rations to try to maintain the ruminal environment within physiological parameters. There is, however, no knowledge about the influence of other factors such as climate and environmental conditions on ruminal physiology.

The influence of climate on cattle has been recognized [8]. Thus, the physiology, behaviour and health of livestock are markedly influenced by the environment in which they live $[9,10]$, whose effects on animals are mediated by metabolic, physiological and ethological responses. These are more or less accentuated depending on breed, age, productive level and individual characteristics [8].

To cope with adverse weather conditions, animals modify their physiological and behavioural mechanisms in order to maintain their body temperature within a normal range. As a consequence, it is possible to observe alterations in food consumption and behaviour. Under extreme conditions of cold or heat [11] animal response can be so marked that it may have a direct influence on the ruminal environment, as indicated by different authors [8,12-16]. Even so, the potential impact of weather variations on Lidia cattle, the paradigm of breeding under conditions of freedom at the mercy of environmental conditions, has barely.

Therefore, the objective of this work is to study the relationship between the meteorological parameters (humidity, rainfall, temperature and wind speed) and the conditions ( $\mathrm{pH}$ and temperature) of the ruminal environment of Lidia breed cattle reared in freedom.

\section{Materials and Methods}

\section{Animals and diets}

Five four-year-old Lidia Bulls were used. Animals were handled according to the usual management in their farm, (Tejeda y Segoyuela (Salamanca, Spain; $40^{\circ} 37^{\prime} 56^{\prime \prime} \mathrm{N}^{\circ}$ 01' 21" O; $927 \mathrm{~m}$ above sea level, Köppen- Geiger's climate classification: $\mathrm{Csb}$ ), and were fed on a total

*Corresponding author: García JJ, Sub-Directorate for Research and Technology, Agricultural Technology Institute of Castile and León, Ministry of Agriculture and Livestock, Castilla and Leon Meeting, avd. Filiberto Villalobos, 5 37770 Guijuelo, Salamanca, Spain, Tel: +34923580688; E-mail: gargarjj@itacyl.es

Received February 16, 2018; Accepted March 28 2018; Published March 29 2018

Citation: García JJ, Bartolomé DJ, Posado R, Zúñiga JA, Montañés M, et al. (2018) Weather Conditions and Rumen Temperature and $\mathrm{pH}$ in Lidia Cattle. J Vet Sci Technol 9: 532. doi: 10.4172/2157-7579.1000532

Copyright: @ 2018 García JJ, et al. This is an open-access article distributed under the terms of the Creative Commons Attribution License, which permits unrestricted use, distribution, and reproduction in any medium, provided the original author and source are credited. 
mixed ration (TMR) whose ingredients and chemical composition are showed in Tables 1 and 2, respectively. All the animals received the same feeding, approximately $10 \mathrm{~kg} / \mathrm{animal}$ and day of the indicated mixture, supplied by an unifeed wagon once a day in the morning. The management of the animals was carried out in accordance with the Directive 2010/63/EU on the protection of animals used for scientific purposes, and Regulation (EC) $1 / 2005$, concerning the protection of animals during transportation and related operations. The bulls had a fenced space of 17 ha of pasture land, which would allow them to express their grazing behaviour patterns in freedom with full normality. The experimental period lasted from September to November.

\section{Rumen $\mathrm{pH}$ and temperature}

Rumen $\mathrm{pH}$ and temperature were measured using internal wireless smaXtec ${ }^{\circledR}$ boluses (SmaXtec animal care salts GmbH, GRAZ, Austria), developed and evaluated by Gasteiner and Cols [17]. This bolus (132 $\times 35 \mathrm{~mm}$ size $)$ records $\mathrm{pH}(0-14 \pm 0.2$ units $)$ and temperature (25-50 $\pm 0.2^{\circ} \mathrm{C}$ ) every 10 minutes during the entire experimental period of measurement ( $37 \pm 8.2$ days).

Each bolus was adjusted using $\mathrm{pH} 4$ and 7 standards before being used. Once calibrated, the bolus was orally introduced with an applicator to be hosted in the reticulum, where it remained until the animal was slaughtered Data were recorded by using a mobile reader and displayed using a particular software (SmaXtec).

Meteorological parameters: The data of temperature, relative humidity, rainfall and wind speed was recorded and provided by the AEMET (State Meteorological Agency).

For the study of the joint effect of the meteorological parameters on the animals, the following indices have been calculated:

Temperature and humidity index (THI) [18]:

$\mathrm{THI}=(1.8 \mathrm{~T}+32)-(0.55-0.55 \mathrm{RH} / 100)(1.8 \mathrm{~T}-26)$

Thermal sensation or apparent temperature [19]:

$\mathrm{T}$ app. $\left({ }^{\circ} \mathrm{C}\right)=33+(\mathrm{T}-33) \times(0.474+0.454 \sqrt{ }(\mathrm{W})-0.0454 \mathrm{~W})$

Cooling index: $[19,20]$

$\mathrm{CI}=0.323 \times(18.97 \times \sqrt{ }(\mathrm{W})-\mathrm{W}+37.62) \times(33-\mathrm{T})$,

where $\mathrm{T}$ is the ambient temperature $\left({ }^{\circ} \mathrm{C}\right), \mathrm{RH}$ the relative humidity (\%), T app. the apparent temperature and $\mathrm{W}$ the wind speed $(\mathrm{km} / \mathrm{h})$.

Analytical determinations: Feed samples were analyzed following the procedures of the AOAC [21] to determine their content of dry matter (934.01), ashes (942.05), crude protein (Nx6.25: 976.06) and crude fiber (962.09). The analytical determinations were carried out in the facilities of MasterLab España Analytical Services (Tres Cantos, Madrid)

Statistical analysis: Data on rumen $\mathrm{pH}$ and temperature were first averaged for each day: maximum, minimum and mean, area under the curve, and time spent below $\mathrm{pH}$ thresholds of 7.0, 6.6, 6.2, 5.8, 5.4 and 5.0. The area under the curve was calculated by multiplying the absolute value of the deviation in $\mathrm{pH}$ by the time $(\mathrm{min})$ the $\mathrm{pH}$ was below the threshold, and expressed as $\mathrm{pH}$ units $\times$ min. The value of the average $\mathrm{pH}$ for each hour within each day was also calculated for each animal.

For the temperature analysis, the maximum, minimum and mean data were processed, time below 38.4 and above 39.0, 39.2, 39.4, 39.6 and $39.8^{\circ} \mathrm{C}$. The area under the curve was calculated as indicated for $\mathrm{pH}$. The beginning of a drink event was identified when the ruminal temperature suffered a decrease higher than $0.28^{\circ} \mathrm{C}$ from the previous measurement; and the end of the drinking period was considered when the temperature ceased to increase its values during a period of 10 minutes [22].

Pearson's linear correlation analysis was performed among the different variables using the software SPSS 16.0 for Windows (IBM Corp., New York, USA).

\section{Results and Discussion}

The physical-environmental factors affecting livestock were defined by Hahn and Cols [13] and correspond to a complex interaction of air temperature, relative humidity, radiation, wind speed, precipitation, atmospheric pressure, ultraviolet light and dust. This work will focus on those parameters that are more easily measurable and whose influence could be more decisive, such as temperature, relative humidity, wind speed and precipitation, and the relationship that these variables can have with rumen $\mathrm{pH}$ and temperature.

Table 3 shows the average values for each of the controlled parameters, whereas Table 4 shows the correlation coefficients between the daily average values of the ruminal parameters $(\mathrm{pH}$ and temperature) and the meteorological parameters analyzed (relative humidity, rainfall, temperature and wind speed).

A certain positive correlation (although very weak) was observed between the recorded rainfall and the time the rumen passes at $\mathrm{pH}<5.0$ and the average and minimum rumen temperature. It is estimated that rainfall temporarily decreases feed consumption by 10 to $30 \%$, while the presence of mud (as a consequence of rain) can decrease feed intake up to $30 \%$ [23]. Therefore, rainfall can lead to changes in the pattern of feed intake, reducing the number of intakes per day, which could be associated with a reduction in total feed intake. The reduction in the number of meals per day could be offset by an increase in the amount of feed eaten in each of them [24-26], causing a deregulation of the physiological mechanisms to maintain ruminal $\mathrm{pH}$ within neutrality [27]. Thus, the correlation between rainfall and the time that rumen $\mathrm{pH}$ is low could therefore be explained by a decrease in the number of meals associated with an increase in the amount of feed taken in each of them.

\begin{tabular}{|c|c|c|}
\hline Ingredients (\% on fresh matter) & Feed & Ration \\
\hline Barley & 27 & \\
\hline Corn & 34.36 & \\
\hline Beet pulp & 10 & \\
\hline Salt & 0.35 & \\
\hline DDG & 7 & \\
\hline Rapeseed 36 & 10 & \\
\hline Soybean 44 & 5.05 & \\
\hline Soybean oil & 1 & \\
\hline Calcium carbonate & 1.4 & \\
\hline Phosphate & 0.37 & \\
\hline Fat by pass ${ }^{1}$ & 1.97 & \\
\hline Vitamin-mineral premix $^{2}$ & 0.5 & \\
\hline Buffer & & \\
\hline Fodder & 1 & \\
\hline Cereal Straw & -- & 61.91 \\
\hline Cane molasses & -- & 33.33 \\
\hline
\end{tabular}

${ }^{1}$ Hepagras JC Trow Nutition, Madrid, Spain; ${ }^{2}$ Ternimax51 TLIDI, Trow Nutition, Madrid, Spain; ${ }^{3}$ Biomax ( $75 \%$ Sodium bicarbonate, $25 \%$ Magnesium oxide), Trow Nutition, Madrid, Spain.

Table 1: Ingredients of the rations used. 


\begin{tabular}{|c|c|c|}
\hline Chemical composition (\% on dry matter) & Feed & Ration \\
\hline Moisture & 10.6 & 9.6 \\
\hline Crude protein & 13.4 & 10.8 \\
\hline Ashes & 5.6 & 6.5 \\
\hline Crude fiber & 9.4 & 14.7 \\
\hline Starch & 33 & 23.1 \\
\hline Crude fat & 4.93 & 4.1 \\
\hline Non-fibrous carbohydrates & & 27.7 \\
\hline
\end{tabular}

Table 2: Chemical composition of the ration.

\begin{tabular}{|c|c|c|c|c|}
\hline & Average & Typ. deviation & Minimum & Maximum \\
\hline \multicolumn{5}{|c|}{ Rumen parameters } \\
\hline Temperature & 38.88 & 0.38 & 38.4 & 39.3 \\
\hline Mean pH & 6.22 & 0.06 & 6.16 & 6.29 \\
\hline Minimal pH & 5.52 & 0.05 & 5.45 & 5.58 \\
\hline Maximum pH & 6.81 & 0.1 & 6.7 & 6.94 \\
\hline Maximum temperature & 40.07 & 0.3 & 39.7 & 40.46 \\
\hline Minimal temperature & 31.9 & 1.09 & 30.7 & 33.2 \\
\hline \multicolumn{5}{|c|}{ Weather parameters } \\
\hline Maximum relative humidity & 87.55 & 15.09 & 35 & 100 \\
\hline Minimal relative humidity & 47.65 & 21.82 & 7 & 100 \\
\hline Rainfall & 17 & 53 & 0 & 568 \\
\hline Maximum temperature & 16.5 & 8.24 & -0.1 & 35.8 \\
\hline Minimal temperature & 5.8 & 5.62 & -7 & 19.9 \\
\hline Mean temperature & 11.2 & 6.83 & -3.6 & 27.8 \\
\hline Wind speed & 41.66 & 14.75 & 15 & 94 \\
\hline
\end{tabular}

Table 3: Mean values for each of the variables.

Conversely, there is a negative correlation between rainfall and the time the rumen spends at low temperatures (related to the moments when the animal drinks water). This relationship could probably be due to the fact that the animals will tend to consume less amount of water on rainy days. This would be explained by the fact that the higher relative humidity of the air, the lower the water losses (mainly through breathing and skin) [28].

In any case, and despite the fact that both correlations are significant, the correlation coefficient is low. This may be due, in the first place, to the fact that during the development of this experimental protocol rainfall was recorded during $20 \%$ of the days. In addition, the different intensity at which the precipitation occurred could have contributed to the unexplained variability (Figure 1).

A positive correlation was observed between relative humidity and the time that the rumen is at low $\mathrm{pH}$ values, which, in accordance with the above mentioned rainfall hypothesis, may be associated with a high amount of feed per meal, despite the fact that total feed intake may decrease in environments with mud and humidity [23]. However, the relationship between relative humidity and rumen temperature is inverse: the higher the humidity, the lower the ruminal temperature and the less the time that rumen passes at high temperatures. The reduction of intake in humid environments could cause the ruminal temperature to be slightly lower due to a decrease in ruminal metabolism [29]. In addition, in the present work a negative and significant correlation between mean rumen temperature and the time the rumen passes at low $\mathrm{pH}$ was observed. However, in highly productive cattle (intensively producing meat or milk), the relative humidity has hardly an influence, provided that the temperatures are in the zone of thermoneutrality; However, when temperatures are outside the thermoneutral zone, a high relative humidity can have a negative effect on animal welfare [30].

The relative humidity during the development of this study (Table
3 ) is between 87.5 and $47.6 \%$, with an average value of $67.6 \%$, these values being, therefore, within the optimal range indicated by Aldaz and Cols [31]. There is a range of ambient temperature within which the body temperature remains constant with a minimum effort for the thermoregulatory mechanisms and within which the sensation of heat or cold it is absent (B 'to B), known as thermal comfort or thermoneutrality zone (Figure 2). This zone is between $-1^{\circ} \mathrm{C}$ and $16^{\circ} \mathrm{C}$ for the bovine breeds in carnivorous habitat typical of the temperate zones. The NRC considers the thermal control zone for Holstein cattle in a range between -5 and $27^{\circ} \mathrm{C}$. Johnson situates it between $-5^{\circ} \mathrm{C}$ and $21^{\circ} \mathrm{C}$, whereas Aldaz and Cols consider intermediate zone (between -5 and $\left.25^{\circ} \mathrm{C}\right)$ [31-33].

The environmental temperature has a clear influence on the ruminal temperature. Thus, there is a positive correlation between both parameters and with the time the rumen passes at high temperatures [34], even though the present experiment has been carried out in thermoneutrality conditions (average environmental temperature of $10^{\circ} \mathrm{C}$ ). Therefore, predictably, it would not be necessary for the animal to set in motion compensation mechanisms. Analogously, a negative and significant correlation between ambient temperature and time spent at low temperatures was also observed.

There also seems to be a certain negative correlation between the ambient temperature and the time the rumen passes at $\mathrm{pH}<5.4$. When the environmental temperature decreases, the animals need to start mechanisms to compensate for the loss of heat through strategies that foresee, in the long term, an increase in isolation with the environment (greater fat cover, longer and thicker fur, etc.), and, in the short term, behavioral (postural variations to try to reduce the exposure of the body surface and thus the potential heat loss), physiological (peripheral vasoconstriction and generalized pilo-erection) changes or producing more heat through an increase in feed intake, most likely a combination of several mechanisms [33,35-37]. In addition, the activation of thermogenesis processes to cope with cold environments causes a reduction in digestibility of 0.2 units per degree Celsius, thus increasing maintenance needs [37]. As a consequence, in these cases, both feed and water consumption may be affected. Thus, animals increase feed intake when environmental temperatures fall below the thermoneutral zone or, alternatively, change their diets to feed sources that allow them to obtain the extra energy required to increase heat production and satisfy the increase in maintenance needs [37]. In this way, the animal can increase the production of volatile fatty acids in the rumen, which would lead to a decrease in ruminal $\mathrm{pH}$ and, consequently, cause the rumen to spend more time at low $\mathrm{pH}$. The alteration in feeding behavior has been observed in bovines, generally,

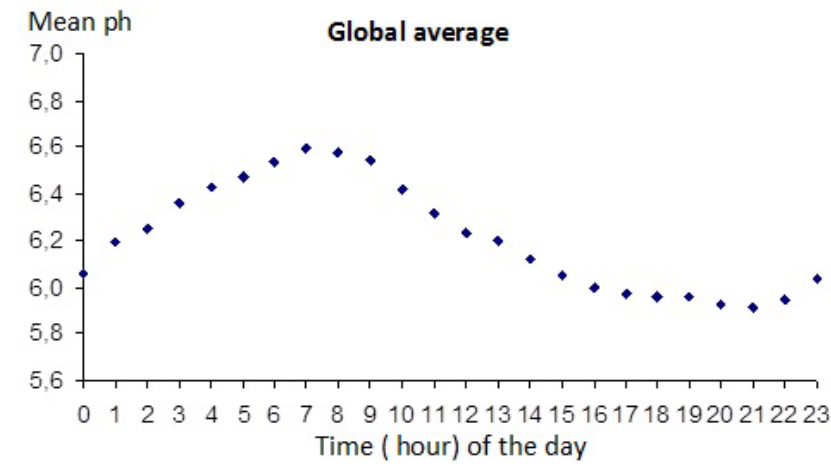

Figure 1: Average $\mathrm{pH}$ value throughout the day. 
Citation: García JJ, Bartolomé DJ, Posado R, Zúñiga JA, Montañés M, et al. (2018) Weather Conditions and Rumen Temperature and pH in Lidia Cattle. J Vet Sci Technol 9: 532. doi: 10.4172/2157-7579.1000532

Page 4 of 6

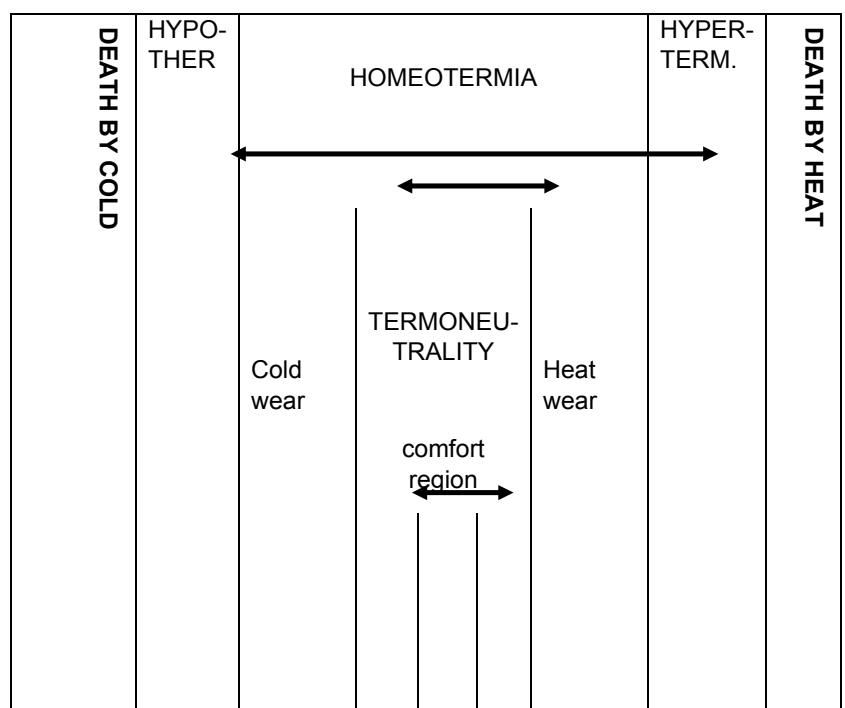

B: Lowest critical temperature; B': Highest critical temperature.

Figure 2: Fuente Resano, 2004. under very low temperatures $\left(-10^{\circ} \mathrm{C}\right)$ [38]. Although the temperatures recorded during the experimental period were not so extreme (positive temperature values but close to $0^{\circ} \mathrm{C}$ ), they could have an effect on feed intake. Indeed, it has been observed that the infusion of cold water in the rumen $\left(5^{\circ} \mathrm{C}\right)$ produces an increase in feed consumption by $24 \%$ [39].

The results obtained in this study agree with those published by Gianesella, who showed the influence that humidity and environmental temperature have on the ruminal environment [15].

An inverse relationship between environmental temperature and voluntary feed intake has been well documented [23,40-42] especially when using high energy density diets [14]. In addition, infusion of hot water $\left(49^{\circ} \mathrm{C}\right)$ in the rumen depresses feed intake by $9 \%$ [39]. However, this decrease in feed consumption is not always accompanied by an increase in ruminal $\mathrm{pH}$. Thus, in accordance with Church, Kaiser and Weniger reported a decrease in rumen $\mathrm{pH}$ associated to an increase in environmental temperature regardless the diet received by the animals (lambs receving oats straw or concentrate and hay), and due to an increase of the concentration of volatile fatty acids $[43,44]$. Likewise, Collier also indicated that ruminal $\mathrm{pH}$ decreased in conditions of thermal stress due to high temperatures [12]. This phenomenon

\begin{tabular}{|c|c|c|c|c|c|c|c|}
\hline \multirow{3}{*}{$\begin{array}{l}\text { Rumen parameters } \\
n=189 \text { (all) }\end{array}$} & \multicolumn{7}{|c|}{ Weather parameters } \\
\hline & \multicolumn{2}{|c|}{ Relative humidity } & \multirow[t]{2}{*}{ Rainfall } & \multicolumn{3}{|c|}{ Temperature } & \multirow[t]{2}{*}{ Wind speed } \\
\hline & Max & Min & & Max. & Min. & Mean. & \\
\hline \multicolumn{8}{|c|}{$\mathrm{pH}$} \\
\hline Mean. & 0.047 & -0.062 & -0.036 & 0.009 & 0.017 & 0.013 & 0.076 \\
\hline Min. & 0.113 & -0.022 & -0.076 & -0.047 & -0.064 & -0.056 & 0.07 \\
\hline Max. & -0.03 & -0.085 & 0.032 & 0.054 & 0.081 & 0.067 & 0.09 \\
\hline \multicolumn{8}{|c|}{ Time $(\mathrm{min} /$ day $)$ at $\mathrm{pH}<$} \\
\hline 7.0 & -0.057 & 0.031 & 0.001 & 0.028 & 0.058 & 0.042 & 0.031 \\
\hline 6.6 & -0.086 & -0.005 & -0.026 & 0.059 & 0.064 & 0.063 & -0.042 \\
\hline 6.2 & -0.084 & 0.02 & 0.017 & 0.041 & 0.017 & 0.032 & -0.097 \\
\hline 5.8 & -0.013 & 0.089 & 0.064 & -0.032 & -0.045 & -0.039 & -0.074 \\
\hline 5.4 & 0.082 & $0.217^{* *}$ & 0.109 & $-0.194^{*}$ & $-0.165^{*}$ & $-0.189^{* *}$ & 0.021 \\
\hline 5.0 & 0.139 & $0.255^{\star \star}$ & $0.180^{*}$ & $-0.263^{\star *}$ & $-0.207^{\star *}$ & $-0.248^{\star \star}$ & 0.032 \\
\hline \multicolumn{8}{|c|}{ Temperature } \\
\hline Mean. & -0.133 & $-0.264^{\star *}$ & $0.203^{\star *}$ & $0.404^{* *}$ & $0.440^{* *}$ & $0.431^{* *}$ & -0.052 \\
\hline Max. & -0.05 & $-0.176^{*}$ & 0.037 & $0.261^{* *}$ & $0.248^{* *}$ & $0.265^{\star *}$ & -0.135 \\
\hline Min. & -0.094 & $-0.144^{*}$ & $0.264^{* *}$ & $0.335^{\star *}$ & $0.361^{* *}$ & $0.357^{* *}$ & -0.064 \\
\hline \multicolumn{8}{|c|}{ Time (min/day) at temperature> } \\
\hline 39.0 & $-0.250^{\star *}$ & $-0.384^{\star *}$ & 0.128 & $0.530^{* *}$ & $0.527^{\star *}$ & $0.546^{* *}$ & -0.099 \\
\hline 39.2 & $-0.224^{\star \star}$ & $-0.367^{\star *}$ & 0.141 & $0.493^{\star *}$ & $0.492^{* *}$ & $0.509^{\star *}$ & -0.083 \\
\hline 39.4 & $-0.174^{*}$ & $-0.301^{* *}$ & $0.163^{*}$ & $0.401^{* *}$ & $0.418^{\star *}$ & $0.421^{\star *}$ & -0.048 \\
\hline 39.6 & -0.104 & $-0.221^{\star *}$ & $0.154^{*}$ & $0.316^{\star *}$ & $0.357^{\star *}$ & $0.343^{* *}$ & -0.032 \\
\hline 39.8 & -0.066 & $-0.164^{*}$ & 0.125 & $0.245^{\star *}$ & $0.299^{* *}$ & $0.275^{\star *}$ & -0.028 \\
\hline $\begin{array}{l}\text { Time }(\mathrm{min} / \text { day }) \text { at } \\
\text { temperature }<38.4\end{array}$ & 0.025 & 0.095 & $-0.239^{\star *}$ & $-0.231^{* *}$ & $-0.275^{\star \star}$ & $-0.256^{\star \star}$ & 0.011 \\
\hline
\end{tabular}

Significant correlation at $\mathrm{P}<0.05$. ${ }^{*}$ Significant correlation at $\mathrm{P}<0.01$.

Table 4: Correlation coefficients (Pearson) between the daily mean values of rumen parameters and meteorological parameters. 
could be explained by the fact that the particles retention time in the rumen increases due to a diminished rumen motility, thus increasing digestibility [45]. In addition, an increase in the size of meals has been linked to high environmental temperatures, thus increasing the risk of accumulation of large amounts of volatile fatty acids and, therefore, the risk of acidosis [46].

The wind speed does not seem to influence the ruminal environment in the present experiment. However, other authors indicate that in conditions of low environmental temperatures the wind does have a negative effect, since it increases the heat loss [47,48], which could trigger the start of compensation mechanisms, and therefore the increase of dry matter consumption with the possible effect that this can have on the ruminal $\mathrm{pH}$.

The main climatic problem observed is the associated effect of rainfall and wind, because the animals stop eating in the simultaneous presence of both weather events [49]. To assess the joint effect of these meteorological phenomena, there are some indicators, such as the temperature and humidity index (THI) [18], the thermal sensation or apparent temperature [19] and the cooling index [20].

When analyzing all the information, it is observed that there is a significant positive correlation between ruminal temperature and THI and thermal sensation (Table 5). This is in agreement with the general tendency observed, in the present work, between ruminal and environmental temperature. Although there is some divergence with the data shown on the correlation between ruminal temperature and environmental relative humidity, it must be taken into account that the weight of this last parameter within the calculation of THI and thermal sensation is lower than that given to the temperature. Indeed, temperature determines to a greater extent the value of the THI and, consequently, its relation with the rest of the parameters studied. Likewise, the negative correlation between ruminal temperature and cooling index follows the same tendency between environmental and ruminal temperature, since this index is inverse to the temperature.

When only data from temperatures above the thermoneutrality $\left(>16^{\circ} \mathrm{C}\right)[30]$ are considered (Table 6), no significant correlation is observed among the variables studied. This could be due, firstly, to the fact that although these values are considered outside the comfort zone, the maximum temperatures reached (average $19^{\circ} \mathrm{C}$, maximum $27.8^{\circ} \mathrm{C}$ ) are not extreme enough to activate the mechanisms of compensation that may cause alterations at the ruminal level. And, secondly, the scarce thermal amplitude covered by the data set and the variability of said ruminal temperature values taken from the animals. All this has been able to contribute to that there is no obvious association between the variables studied.

Taking into account the data pairs corresponding to temperatures below (or equal to) $16^{\circ} \mathrm{C}$ (Table 7), a positive correlation between rumen temperature and THI and thermal sensation is observed, and negative with the cooling index, as indicated previously (Table 5). In this case, the number of data considered is greater, as is the thermal amplitude taken into account. This observation confirms the influence of the environmental temperature on the ruminal temperature in the thermoneutrality zone.

Furthermore, the ruminal $\mathrm{pH}$ correlated positively with the THI and the thermal sensation, and negatively with the cooling index. As discussed above in relation to $\mathrm{pH}$ and environmental temperature, when the animal loses heat, thermogenesis mechanisms are activated and food consumption increases, which, ultimately, ends up in a decrease in ruminal $\mathrm{pH}$.

\begin{tabular}{|c|c|c|}
\hline \multirow{2}{*}{$(\mathbf{n = 1 8 8})$} & \multicolumn{2}{|c|}{ Average ruminal parameters } \\
\cline { 2 - 3 } & Temperature & $\mathbf{p H}$ \\
\hline THI for max. humidity & $0.453^{\star *}$ & 0.034 \\
\hline THI for min. humidity & $0.459^{* *}$ & 0.069 \\
\hline Thermal sensation & $0.423^{\star *}$ & -0.009 \\
\hline Cooling index & $-0.423^{* *}$ & 0.009 \\
\hline
\end{tabular}

** Significant correlation to $\mathrm{P}<0.01$.

Table 5: Correlation coefficients (Pearson) between the daily average values of $\mathrm{pH}$ and ruminal temperature and the calculated meteorological parameters.

\begin{tabular}{|c|c|c|}
\hline \multirow{2}{*}{$(\mathbf{n = 7 2 )}$} & \multicolumn{2}{|c|}{ Average ruminal parameters } \\
\cline { 2 - 3 } & Temperature & $\mathbf{p H}$ \\
\hline THI for max. humidity & -0.029 & -0.093 \\
\hline THI for min. humidity & -0.012 & -0.071 \\
\hline Thermal sensation & -0.03 & -0.195 \\
\hline Cooling index & 0.03 & 0.195 \\
\hline
\end{tabular}

Table 6: Correlation coefficients (Pearson) between the daily values of $\mathrm{pH}$ and ruminal temperature and the meteorological parameters calculated when the ambient temperature was higher than $16^{\circ} \mathrm{C}$

\begin{tabular}{|l|l|l|}
\hline \multirow{2}{*}{\multicolumn{1}{|c|}{$(\mathbf{n = 1 1 6 )}$}} & \multicolumn{2}{c|}{ Average ruminal parameters } \\
\cline { 2 - 3 } & \multicolumn{1}{|c|}{ Temperature } & \multicolumn{1}{c|}{ pH } \\
\hline THI for max. humidity & $0.594^{* *}$ & $0.373^{\star *}$ \\
\hline THI for min. humidity & $0.574^{* *}$ & $0.401^{* *}$ \\
\hline Thermal sensation & $0.542^{* *}$ & $0.312^{* *}$ \\
\hline Cooling index & $-0.542^{* *}$ & $-0.312^{* *}$ \\
\hline
\end{tabular}

**Significant correlation to $\mathrm{P}<0.01$.

Table 7: Correlation coefficients (Pearson) between the daily values of $\mathrm{pH}$ and ruminal temperature and the meteorological parameters calculated when the ambient temperature was less than or equal to $16^{\circ} \mathrm{C}$

\section{Conclusions}

A direct correlation between environmental and ruminal temperature has been observed. Even within the range of thermal comfort, environmental relative humidity and rainfall predispose the rumen of Lidia cattle to remain longer at low $\mathrm{pH}$ values. This fact may be associated with an increased risk of ruminal acidosis.

\section{Acknowledgements}

This work has been funded by Garcisan Distribuciones S.L through the project entitled: "Monitoring of the ruminal environment during the bullfighting phase of the fighting bull".

\section{References}

1. Fernández J (2005) Evolution of livestock farms. In: A century of bulls 19052005. Union of Livestock Bullfighters, Madrid, pp: 127-159.

2. Richards SA (1973) Temperature regulation. Wykeham Publications, London, Great Britain, p: 212

3. Yousef MK (1985) Stress Physiology: Definition and terminology. In: Youse MK (ed.) Stress physiology in Livestock Volume I Basic Principles. CRC Press, Boca Raton, Florida, USA, pp: 3-8.

4. Arriola J (1998) Ruminal acidosis in the fighting bull (II). Angry bull 14: 30-35.

5. Carbonell A, Gómez A (2001) The feeding of the fighting bull. Application in Jaralta cattle. Collection: Livestock - Animal Feed Series. Edited by: Ministry of Agriculture and Fisheries of the Junta de Andalucía.

6. Carmona A (1994) Modern techniques in the feeding of the fighting bull. Taurine World Veterinary Congress, Zaragoza, pp: 47-58.

7. Bartolomé DJ (2009) Influence of ruminal acidosis on the fall syndrome and the ethological response of the Bull of Lydia in the square. Doctoral thesis, University of León. 
Citation: García JJ, Bartolomé DJ, Posado R, Zúñiga JA, Montañés M, et al. (2018) Weather Conditions and Rumen Temperature and pH in Lidia Cattle. J Vet Sci Technol 9: 532. doi: 10.4172/2157-7579.1000532

8. Johnson HD (1987) Bioclimates and livestock. In: HD Johnson (edn.) Bioclimatology and the adaptation of livestock. St. Louis MO: Elsevier, pp: 3-15.

9. Balling RC (1980) An assessment of the impact of weather conditions on feedlot cattle performance. Center for Agricultural Meteorology and Climatology, University of Nebraska-Lincoln, Lincoln, NE, CAMaC Progress report, pp: 8083.

10. MAFF (Ministry of Agriculture, Fisheries and Food) (2000) Climate change and agriculture in the United Kingdom. PB4876, Summary A4.

11. Arias RA (2006) Environmental factors affecting daily water intake on cattle finished in feedlots. J Anim Sci 89: 245-251.

12. Collier RJ, Doelger SG, Head HH, Thatcher WW, Wilcox CJ (1982) Effects of heat stress during pregnancy on maternal hormone concentrations, calf birth weight and postpartum milk yield of Holstein cows. J Anim Sci 54: 309-319.

13. Hahn GL, Mader TL, Eigenberg RA (2003) Perspectives on development of thermal indices for animal studies and management. Proc Symp Interactions between climate and animal production, EAAP Technical series, pp: 31-44

14. Nienaber JA, Hahn GL, Brown-Brandl TM, Eigenberg RA (2003) Heat stress climatic conditions and the physiological responses of cattle. In 5th International Dairy Housing Conference for 2003, Fort Worth Texas, USA. ASAE publication; pp: 255-262.

15. Gianesella M, Piccione G, Cannizzo C, Casella S, Morgante M (2012) Influence of temperature and humidity on rumen $\mathrm{pH}$ and fatty acids in dairy cows. J Environ Biol 33: 1093-1096.

16. Frank KL, Mader TL, Harrington JA, Hahn GL, Davis MS (2001) Climate change effects on livestock production in the Great Plains. In: Livestock Environment VI: Proceedings of the 6th International Symposium, Louisville, Kentucky, USA ASAE Publication, pp: 351-358.

17. Gasteiner J, Fallast M, Rosenkranz S, Häusler J, Schneider K, Guggenberger $\mathrm{T}$ (2009) Measuring rumen $\mathrm{pH}$ and temperature by an indwelling and data transmitting unit and application under different feeding conditions. In 4th European Conference on Precision Livestock Farming, Wageningen Publishers, pp: 127-133.

18. Valtorta SE, Gallardo MR, Castro HC, Castelli ME (1996) Artificial shade and supplementation effects on grazing dairy cows in Argentina. Trans Am Soc Agric Eng 39: 230-236.

19. Siple PA, Passel CF (1945) Measurements of dry atmospheric cooling in subfreezing temperatures. Proceedings of the American Philosophical Society 89: $177-199$

20. Abreu A (2009) Environmental pollution. Atlantic International University Honolulu, Hawai, pp: 1-170.

21. AOAC (2003) Official methods of analysis. 17th Edn. AOAC International Gaithersburg, USA.

22. Dye TK, Richards CJ (2008) Effect of water consumption on rumen temperature. J Anim Sci 86: 114

23. National Research Council (NRC) (1991) Ending Mandatory Retirement for Tenured Faculty. The consequences for higher education, Washington DC National Academy Press.

24. González LA, Ferret A, Manteca X, Ruíz JL, Calsamiglia S, et al. (2008) Performance, behavior, and welfare of Friesian heifers housed in pens with two, four, and eight individuals per concentrate feeding place. J Anim Sci 86 1446-1458.

25. Livshin N, Maltz E, Edan Y (1995) Regularity of Dairy Cow Feeding Behavior with Computer-Controlled Feeders. J Dairy Sci 78: 296-304.

26. Robles V, González LA, Ferret A, Manteca X, Calsamiglia S (2007) Effects of feeding frequency on intake, ruminal fermentation, and feeding behavior in heifers fed high-concentrate diets. J Anim Sci 85: 2538-2547.

27. Schwartzkopf-Genswein KS, Beauchemin KA, Gibb DJ, Crews DH, Hickman $D D$, et al. (2003) Effect of bunk management on feeding behavior, ruminal acidosis and performance of feedlot cattle: A review. J Anim Sci 81: 149-158.
28. CSIRO (2007) Water intake. In: Nutrients requirements of domesticated ruminants. Commonwealth Scientific and Industrial Research Organisation (CSIRO). CSIRO Publishing, Collingwood, Australia

29. Russell JB (1986) Heat production by ruminal bacteria in continuous culture and its relationship to maintenance energy. J Bacteriol 168: 694-701.

30. Resano M (2004) Environmental Control in Cattle Ranches of Navarra. Navarra Agraria 148: 57-63.

31. Aldaz J, Galduroz GE, Iriarte J, Eslava F, Múgica I, et al. (1997) Techniques of Production of Quality Milk in Cattle Vacuno. Livestock Management Technical Institute, Pamplona, pp: 59-67.

32. Johnson HD (1986) The effects of temperature and thermal balance on milk production. In: Moberg GP (ed.). Limiting the effects of stress on cattle. Western Regional Research Publication 9: 33-45.

33. Bavera GA, Beguet HA (2003) Body thermoregulation and setting Mea Production Bovine FAV UNRC. www.produccion-animal.com.ar (or) www. produccionbovina.com

34. Gengler WR, Martz FA, Johnson HD, Krause GF, Hahn LR (1970) Effect of temperature on food and water intake and rumen fermentation. J Dairy Sci 53 : 434-437.

35. Young BA (1985) Physiological responses and adaptations of cattle. In: Youse MK (ed). Stress physiology in livestock Volume II Ungulates. CRC Press, Boca Raton, Florida, USA

36. Bianca W (1968) Thermoregulation. In: Hafez ES (ed). Adaptation of Domestic Animals. Lea and Febiger, Philadelphia, USA, pp: 97-118.

37. Young BA, Christopherson RJ (1974) Effect of prolonged cold exposure on digestion and metabolism in ruminants. International Livestock Environment Symposium, University of Nebraska-Lincoln, Nebraska, USA, pp: 75-80.

38. Forbes JM (1986) A model of the short term control of feeding in the ruminant: effects of changing animal or feed characteristics. Appetite 1:21-41.

39. Bhattacharya AN, Warner RG (1968) Influence of varying rumen temperature on central cooling or warming on regulation of voluntary feed intake in dairy cattle. J Dairy Sci 51: 1481-1489.

40. Ames DR, Brink DR, Willms CL (1980) Adjusting protein in feedlot diets during thermal stress. J Anim Sci 50: 1-6.

41. Beede DK, Collier RJ (1986) Potential nutritional strategies for intensively managed cattle during thermal stress. J Anim Sci 62: 543-554.

42. Mader T (2003) Environmental stress in confined beef cattle. J Animal Sci 81: 1110-1119.

43. Church DC (1974) Digestive physiology and nutrition of ruminants. Vol. 2 Nutritión. Acribia, Zaragoza, Pp: 61-75.

44. Kaiser DY, Weniger JH (1994) In vivo and in vitro studies on nutrient digestibility and heat production of ruminants under heat stress and at different nutrient supply. 4. In vitro studies-background, experimental design, gas production in relation to incubation temperature, energy content of incubated feeds. Archive for animal breeding 37: 385-399.

45. Tajima K, Nonaka I, Higuchi K, Takusari N, Kurihara M, et al. (2007) Influence of high temperature and humidity on rumen bacterial diversity in Holstein heifers. Anaerobe 13: 57-64.

46. Bach A (2002) Ruminal disorders in dairy cattle: a practical approach. FEDNA XVII 18: 119-142.

47. Fox DG, Tylutki TP (1998) Accounting for the effects of environment on the nutrient requirements of dairy cattle. J Dairy Sci 81: 3085-3095.

48. Keren EN, Olson BE (2006) Thermal balance of cattle grazing winter range: Model application. J Anim Sci 84: 1238-1247.

49. Brosh A, Aharoni Y, Degen A, Wright D, Young BA (1998) Effects of solar radiation, dietary energy, and time of feeding on thermoregulatory responses and energy balance in cattle in a hot environment. J Anim Sci 76: 2671-2677. 